\title{
Revisiting pachyonychia congenita: a case cohort study in 815 patients
}

\author{
Liat Samuelov ${ }^{1}$, Frances Smith², David Hansen ${ }^{3}$, Eli Sprecher ${ }^{1,4}$
}

${ }^{1}$ Division of Dermatology, Tel-aviv Sourasky Medical Center, Tel-aviv, Israel; ${ }^{2}$ Pachyonychia Congenita Project, Holladay, Utah, USA; ${ }^{3}$ Department of Dermatology, University of Utah, Salt Lake City, Utah, USA; ${ }^{4}$ Sackler Faculty of Medicine, Tel-Aviv University, Tel Aviv, Israel

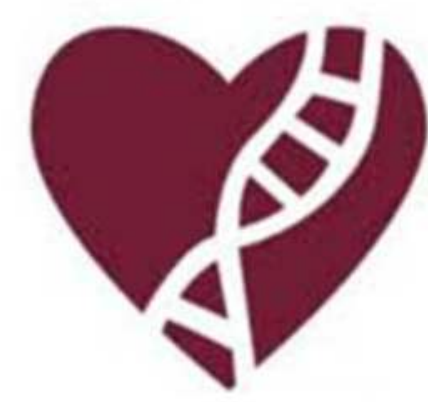

\section{Introduction}

- Pachyonychia congenita (PC) is a group of autosomal dominant disorders caused by mutations in one of 5 keratin genes (KRT6A, KRT6B, KRT6C, KRT16, or KRT17) encoding keratins 6a, 6b, 6c, 16 and 17.

- The most common clinical features of PC (Figure 1) are thickened toenails, palmoplantar keratoderma, epidermal inclusion cysts (mostly steatocystomas and vellus hair cysts), mucosal leukokeratoses, hoarse voice and natal teeth.

- The establishment of an international registry containing both clinical and molecular data led to the development of a disease classification based on the mutant gene and associated features.

- Here we harness the same resource to clarify the prevalence of PCassociated clinical features, delineate phenotype-genotype correlations and identify prognostic features for disease severity.

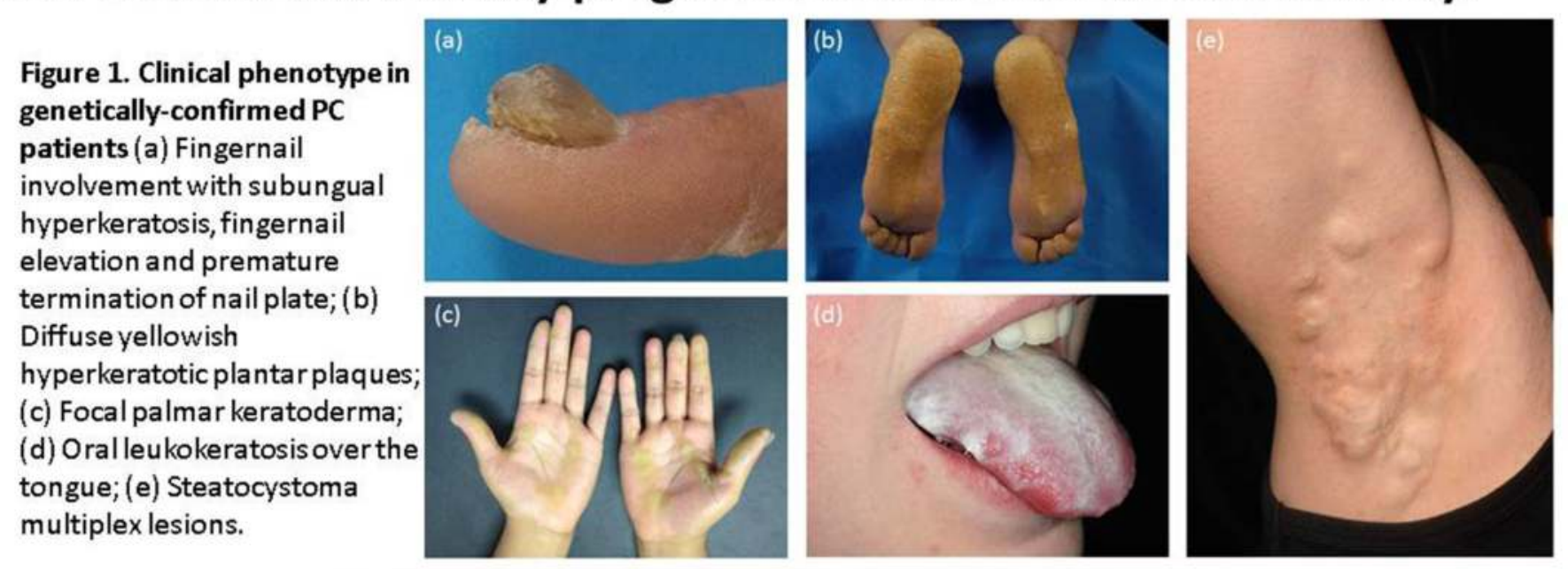

\section{Material and methods}

- 815 individuals with confirmed keratin mutations registered in the International Pachyonychia Congenita Research Registry (IPCRR) were surveyed for clinical findings associated with PC.

- Data were analyzed using various statistical methods including Student T-test, Chi-Square and ANOVA tests for differences in means/proportions. Spearman correlation and logistic regression were used for phenotype-genotype correlations.

\section{Results}

815 PC patients were included in the registry. Table 1 summarizes patients' demographic and molecular data. Mutations in KRT6A and KRT16 were most common followed by mutations in KRT17, KRT6B and KRT6C.

\begin{tabular}{|l|l|}
\hline \multicolumn{1}{|c|}{ Patients characteristics } & \multicolumn{1}{|c|}{ Median; range } \\
\hline & \multicolumn{1}{|c|}{$30 ; 0-87$} \\
\hline Patients' age at evaluation (years) & Number of patients (\%) \\
\hline & $388(48 \%): 427(52 \%)$ \\
\hline Male: female & $332(41 \%)$ \\
\hline Mutated gene & $251(31 \%)$ \\
KRT6A & $134(16 \%)$ \\
KRT16 & $74(9 \%)$ \\
KRT17 & $24(3 \%)$ \\
KRT6B & \\
KRT6C & $249(31 \%): 566(69 \%)$ \\
\hline Mutation type & \\
Spontaneous: Inherited &
\end{tabular}

\section{Phenotypic features of PC}

- Toenail and fingernail dystrophy were evident in $96 \%$ and $75 \%$ of cases, respectively, while all 20 nails were involved in $50 \%$ of cases. More than $50 \%$ of cases demonstrated nails involvement during the first year of life.

- Plantar and palmar keratoderma were reported in $94 \%$ and $70 \%$ of cases, respectively, and in $60 \%$ of cases plantar keratoderma was evident by 4 years of age.

- Oral leukokeratosis, natal teeth and hoarseness were reported in 54\%, $14 \%$ and $24 \%$ of cases, respectively, with the former being evident by 1 year of age in $60 \%$. Cysts were evident in $54 \%$ of cases.

- Ear wax, ear pain and impaired sweating were reported in $28 \%, 14 \%$ and $50 \%$ of cases, respectively. $26 \%$ reported emotional impairments with depression/mood changes being most common. Hearing loss, eye anomalies and hair abnormalities were relatively rare in our cohort and accordingly are probably not directly related to the disease.

\section{Results - cont.}

Effect of PC-associated clinical manifestations on quality of life Plantar keratoderma is the clinical feature associated with the most significant effect on daily function (Table 2). More than $65 \%$ of patients with plantar involvement indicate the persistent effect of this finding which is associated with significant pain in more than $60 \%$ of patients. Other PC-associated clinical features were not associated with a significant effect on quality of life or pain.

\begin{tabular}{|c|c|c|c|c|c|c|}
\hline Impact on QoL & $\begin{array}{c}\text { Plantar } \\
\text { keratoderma }\end{array}$ & $\begin{array}{c}\text { Palmar } \\
\text { keratoderma }\end{array}$ & $\begin{array}{l}\text { Fingernail } \\
\text { dystrophy }\end{array}$ & $\begin{array}{c}\text { Toenail } \\
\text { dystrophy }\end{array}$ & $\begin{array}{c}\text { Oral } \\
\text { leukokeratosis }\end{array}$ & Cysts \\
\hline No impact & $55 / 628(8.7 \%)$ & $268 / 514$ (52.1\%) & $168 / 539(31.1 \%)$ & $187 / 668(28 \%)$ & $182 / 287(63.4 \%)$ & $146 / 386(37.8 \%)$ \\
\hline Sometimes a problem & $148 / 628(23.6 \%)$ & $175 / 514(34 \%)$ & $269 / 539(49.9 \%)$ & $320 / 668(47.9 \%)$ & $88 / 287(30.7 \%)$ & $180 / 386(46.6 \%)$ \\
\hline $\begin{array}{l}\text { Always a problem, able } \\
\text { to function }\end{array}$ & $391 / 628$ (62.3\%) & $66 / 514$ (12.9\%) & 95/539 (17.6\%) & $150 / 668(22.7 \%)$ & $17 / 287(5.9 \%)$ & $52 / 386$ (13.5\%) \\
\hline Impossible to function & $34 / 628(5.4 \%)$ & $5 / 514(1 \%)$ & $7 / 539(1.3 \%)$ & $9 / 668(1.4 \%)$ & $0 / 287(0 \%)$ & $8 / 386(2.1 \%)$ \\
\hline \multicolumn{7}{|l|}{ Associated pain } \\
\hline Not painful & $42 / 739(5.7 \%)$ & $260 / 515(50.5 \%)$ & NA & NA & $197 / 269(73.2 \%)$ & $155 / 384(40.4 \%)$ \\
\hline Sometimes painful & $201 / 739(27.2 \%)$ & $202 / 515(39.2 \%)$ & NA & NA & $69 / 269(25.7 \%)$ & $149 / 384(38.8 \%)$ \\
\hline $\begin{array}{l}\text { Very painful no need } \\
\text { for medications }\end{array}$ & $314 / 739$ (42.5\%) & $25 / 515(4.9 \%)$ & NA & NA & 2/269 (0.7\%) & $45 / 384$ (11.7\%) \\
\hline $\begin{array}{l}\text { Often requires } \\
\text { medications }\end{array}$ & $182 / 739(24.6 \%)$ & $28 / 515(5.4 \%)$ & NA & NA & $1 / 269(0.4 \%)$ & 35/384 (9.1\%) \\
\hline
\end{tabular}

Phenotype-genotype correlations

- KRT6A mutations are associated with youngest age or highest number of fingernails/toenails involvement, oral leukokeratosis and hoarseness while KRT17 mutations are most commonly associated with cysts and natal teeth (Table 3).

- Plantar keratoderma was common among all PC patients regardless of the causative mutation; however palmar keratoderma was most common with KRT16 mutations (Table 3).

- Lack of fingernail involvement was most commonly associated with mutations in KRT16 and KRT6B (57\% and 19\%, respectively).

\begin{tabular}{|c|c|c|c|c|c|}
\hline Mutatedgene & $\begin{array}{l}\text { Toenail } \\
\text { dystrophy }\end{array}$ & $\begin{array}{l}\text { Fingernail } \\
\text { dystrophy }\end{array}$ & Keratoderma & $\begin{array}{l}\text { Mucosal/teeth } \\
\text { involvement }\end{array}$ & Cysts \\
\hline KRT6A & $\begin{array}{c}98 \% \\
\text { Age of onset (y): } 1.2 \\
\text { Meant: } 9.6\end{array}$ & $\begin{array}{c}98 \% \\
\text { Age of onset (y): } 1.1 \\
\text { Meant: } 9.3\end{array}$ & $\begin{array}{l}\text { Plantar: } 93 \% \\
\text { Palmar: } 66 \%\end{array}$ & $\begin{array}{c}\text { Leukokeratosis } 88.3 \% \\
\text { Natal teeth } 3.3 \% \\
\text { Hoarseness } 38.9 \% \\
\end{array}$ & $60.2 \%$ \\
\hline KRT6B & $\begin{array}{c}99 \% \\
\text { Age of onset (y): } 2.8 \\
\text { Mean\#: } 7\end{array}$ & $\begin{array}{c}46 \% \\
\text { Age of onset (y): } 3.5 \\
\text { Mean\#: } 2.4\end{array}$ & $\begin{array}{l}\text { Plantar: } 99 \% \\
\text { Palmar: } 50 \%\end{array}$ & $\begin{array}{c}\text { Leukokeratosis } 24.3 \% \\
\text { Natal teeth } 0 \% \\
\text { Hoarseness } 18.9 \%\end{array}$ & $67.6 \%$ \\
\hline KRT6C & $\begin{array}{c}62 \% \\
\text { Age of onset (y): } 3.2 \\
\text { Mean\#: } 1.6\end{array}$ & $\begin{array}{c}0 \% \\
\text { Age of onset (y): NA } \\
\text { Mean\#: } 0\end{array}$ & $\begin{array}{l}\text { Plantar: } 100 \% \\
\text { Palmar: } 41 \%\end{array}$ & $\begin{array}{c}\text { Leukokeratosis } 21.7 \% \\
\text { Natal teeth } 4.2 \% \\
\text { Hoarseness } 18.2 \%\end{array}$ & $17.4 \%$ \\
\hline KRT16 & $\begin{array}{c}96 \% \\
\text { Age of onset (y): } 2.9 \\
\text { Mean\#: } 6.7 \\
\end{array}$ & $\begin{array}{c}57 \% \\
\text { Age of onset (y): } 3 \\
\text { Meant: } 4.1 \\
\end{array}$ & $\begin{array}{l}\text { Plantar: } 99 \% \\
\text { Palmar: } 86 \%\end{array}$ & $\begin{array}{l}\text { Leukokeratosis } 35.6 \% \\
\text { Natal teeth } 0 \% \\
\text { Hoarseness } 8.1 \% \\
\end{array}$ & $25.6 \%$ \\
\hline KRT17 & $\begin{array}{c}95 \% \\
\text { Age of onset (y): } 1.4 \\
\text { Mean\#: } 8.6 \\
\end{array}$ & $\begin{array}{c}85 \% \\
\text { Age of onset (y): } 1.4 \\
\text { Meant: } 6.9\end{array}$ & $\begin{array}{l}\text { Plantar: } 83 \% \\
\text { Palmar: } 62 \%\end{array}$ & $\begin{array}{c}\text { Leukokeratosis } 26.3 \% \\
\text { Natal teeth } 77.3 \% \\
\text { Hoarseness } 22 \% \\
\end{array}$ & $91.8 \%$ \\
\hline
\end{tabular}

Table 3: Phenotype-genotype correlation

Predictors of clinical outcomes

- Using logistic regression models, increased number of affected toenails and earlier age of toenails involvement predicted fingernail dystrophy while increased number of affected fingernails correlated with toenails involvement $(p<0.0001)$.

- Earlier onset of toenails involvement correlated with plantar keratoderma $(p<0.01)$ while fingernail dystrophy age of onset and walking aids use predicted palmar keratoderma $(p<0.05)$

- Oral leukokeratosis correlated with earlier toenail involvement $(p<0.0001)$, walking aids, nursing difficulties and hoarseness $(p<0.05)$.

- Natal teeth and oral leukokeratosis were inversely correlated whereas natal teeth and cysts significantly predicted each other's development.

\section{Conclusions}

- Here, we establish phenotype-genotype correlations in the largest cohort of PC patients described to date and reveal novel and clinically useful predictors of disease course and manifestations.

\section{References}

1. Eliason et al, J Am Acad Dermatol, 2012; 67: 680-686 2. Wilson et al, J Invest Dermatol, 2010; 130, 425-429.

4. McLean et al, Nat Gnet, 1995; 9:273-278 6. Paller et al, Arch Dermatol, 1991; 127: 701-703. 